\title{
Implementation of Agroforestry Programs in Empowerment of Communities in Jayawijaya Regency
}

\author{
Rudihartono Ismail ${ }^{1}$, Telly Nancy Silooy ${ }^{2}$ \\ \{nancysilooy01@gmail.com $\left.{ }^{2}\right\}$ \\ Universitas Amal Ilmiah YAPIS Wamena, Indonesia ${ }^{1,2}$
}

\begin{abstract}
In the framework of forestry development and in supporting forest and land rehabilitation, the government disburses farmer group empowerment programs with an agroforestry program aimed at farmers inside and outside the forest area to increase production so as to improve the welfare of the community. The aim of the study was to analyze the implementation of agroforestry programs in community empowerment in Jayawijaya District conducted in Walelagama District. The implementation of the community empowerment policy through the Agroforestry program in the context of preserving forest areas in the Walelagama District of Jayawijaya requires an approach both vertically and horizontally, because the efforts to restore forest ecosystems must be carried out by the local government that is supported by a budget and personnel and full community participation and Management Agroforestry programs in the Jayawijaya Regency area are based on three main stages. The implementation of the Agroforestry program in empowering forest communities in Walelagama District in Jayawijaya Regency is strongly influenced by several factors, namely, the bureaucratic structure, resources, and the disposition factor as the attitude of the implementers.
\end{abstract}

Keywords: Implementation, Agroforestry Programs, Community empowerment

\section{Introduction}

Forests are natural resources that need to be preserved and have economic value that can provide benefits in improving the welfare of the community if they can utilize and manage, both timber and non-timber forest products. In the economic field, forest utilization has only been seen as a natural resource producing timber [1]. This causes forest products only to meet the needs of local industries without regard to the value of other benefits that can be obtained from forests and the preservation of forest ecosystems, with such understanding that there is a decrease in forest area [2].

In Law Number 41 of 1999 concerning Forestry article 6 states that the government determines forests based on the main functions, namely: conservation forests, protected forests, and production forests. Conservation forest is a forest area with certain characteristics, which has the main function of preserving the diversity of plants and animals and their ecosystems. In clause 69 and 70 that the community is obliged to participate in maintaining and protecting the forest from destructive disturbances, playing an active role in rehabilitation and conservation, participating in forestry development. While the Government encourages the role of the community through various activities in the forestry sector and is effective and 
effective. So that the farmers are the people that are directly related to the forest rescue and utilization [2].

In the Forestry Minister's Regulation No. P.21 / Menhut-II / 2009 Indonesia's forest area of 120.3 million has a high biodiversity of 30 to 40 thousand species of plants. Forest resources have many benefits besides wood products, forests can also provide benefits in the form of non-timber forest products. Non-timber forest products have so far not been utilized and managed optimally to improve the welfare of communities around the forest. But so far, business development and its utilization have not been done well so that it has not been able to improve the economy of the community, because all this time the collection is only from natural forests, not from cultivation so that natural forests are damaged so there is no supply. Non-timber forest products such as rattan, bamboo, agarwood, red fruit, sago and others.

Seeing these problems in the context of accelerating poverty reduction through Presidential Regulation No. 15 of 2010 concerning the acceleration of poverty reduction, poverty alleviation programs carried out by the central government, local governments, businesses through social assistance, community empowerment, micro-economic business empowerment and other programs in order to improve the economy. With poverty alleviation based on community empowerment aims to develop the potential of poor groups to be directly involved in development.

Forestry Minister's Regulation Number P.35 / Menhut-II / 2007 concerning Non-Timber Forest Products, the government has an obligation to develop Non-Timber Forest Products. In the context of forestry development and supporting forest and land rehabilitation, the government created a program to empower farmer groups, one of which was the Diversity Development Program with an agroforestry pattern which was directed at developing nontimber forest products such as fruits, food crops, latex shakes, medicinal plants, which can benefit human life and can even provide economic value. The Agroforestry program is a land use system wherein the same land is planted together with forest stands and agricultural crops with the benefit of increasing farmer production and community income so as to improve the welfare of the community. Agroforestry is a land management system to overcome the problem of land availability and increase land productivity. The problem that often arises is the transfer of land functions causing forest land to decrease. Agroforestry programs aim to increase and preserve resource productivity, ultimately to improve the welfare of farmers, especially those in and around forest areas. Development of various forestry businesses carried out in Walelagama District with agroforestry patterns and directed towards the development of non-timber forest products, namely red fruits that have advantages and have high benefits, with the aim of providing superior non-timber forest products to be developed in a direct manner so that they have high economic value both at regional and national levels need to be developed so as to improve the welfare of the community.

Based on the background of the above problems, the problems in this study can be formulated as follows:

1. What is the implementation of the Agroforestry Program in the Empowerment of Walelagama District Community in Jayawijaya Regency?

2. What are the Inhibiting Factors for the Implementation of the Agroforestry Program in Empowering the Walelagama District Community of Jayawijaya Regency?

\section{Literature Review}

\subsection{Implementation of Public Policy for Agroforestry Programs}

Implementation is part of public policy. Implementation plays a very important role in public policy, because a policy will have no meaning if it is not implemented. Through the 
implementation of the policy, plans or programs that are still abstract are attempted to become a reality. As stated by Indonesia Scholar said that policy implementation is a series of activities in order to deliver wisdom to the public so that the policy can bring the expected results [3]. Meanwhile other scholar argues that policy implementation can be seen as a process of implementing policy decisions [4].

In analyzing the implementation of the Agroforestry program the implementation theory was used according to Edward III's model. In Edwards III's view in Gadjah Mada University Scholar, policy implementation is influenced by four variables, namely: (1) communication, (2) resources, (3) disposition, and (4) bureaucratic structure. The four variables are related to each other [5].

\subsection{Agoforestry Program}

Agroforestry program is a form of sustainable land use that combines forestry crops with agricultural crops and / or livestock on the same land for the purpose of enhancing economic, social and ecological development [6]. The existence of the Agroforestry Program is primarily expected to help optimize the results of a sustainable form of land use to ensure and improve food needs. The high rate of population growth indicates that increased food must be available. The achievement of the target of increasing food production can be carried out with an intensification pattern through increasing cultivation technology and extensification, which among others can be done through the expansion of agricultural areas in forest land with agroforestry systems around the forest. The benefits obtained from Agroforestry are increased food production, farmer income, and employment opportunities and quality of community nutrition for the welfare of farmers around the forest. To integrate the sustainability of forest functions and community welfare, the concept of agroforestry was developed [2].

\section{Methods}

The study was conducted in Jayawijaya District with a case study in Walelagama District with 13 people using Purporsive Sampilng. Based on the objectives to be achieved, this study used a qualitative descriptive method. Data collection techniques through Indepth Interview, Participation Observation, and Documentation. The data analysis is done with the following steps:

a) Reduction data, summarizing the data in raw data is selected, simplified and essentially taken.

b) Display data, data is presented in writing based on factual cases that are interrelated. Data display is used to understand what actually happens in the organization.

c) Verification data, draw conclusions on the patterns of order and irregularities that exist in the phenomenon, then make predictions about the next possibility.

\section{Results And Discussion}

\subsection{General Overview in Jayawijaya Regency}

Jayawijaya is a highland valley with an average altitude of +1550 meters above sea level, located at 3.45'-4.2 South Latitude, and 138.3'-139.4 longitude East known as the Baliem Valley surrounded by the Jayawijaya Mountains which is famous for its peak eternal snow peaks, including: Peak of Trikora $(4,750 \mathrm{~m})$, Peak of Mandala $(4,700 \mathrm{~m})$ and Peak of Yamin $(4,595 \mathrm{~m})$. This mountain range is very attractive to tourists and researchers of Natural Sciences because its peaks are always covered with snow despite being in the tropics. Steep mountain slopes and narrow and steep river valleys are characteristic of these mountains. 
Extensive river valley basins exist only in the West Baliem Valley and East Baliem Valley (Wamena). The natural vegetation of wet tropical forests in the lowlands provides opportunities for climate forests to develop rapidly in this valley. Mountain forest ecosystems develop in altitude areas between 2,000-2,500 $\mathrm{m}$ above sea level. Air temperature varies between $10.5 \mathrm{C}$ to $29.4 \mathrm{C}$.

The population of Jayawijaya Regency is based on the 2016 population projection of 210,229 people. Compared to the 2015 projected population, the population of Jayawijaya experienced a growth of 1.89 percent.

\subsection{Overview of Forest Areas in Jayawijaya Regency}

Based on the Minister of Forestry's Decree Number 492 / KPTS-I / 1999 concerning the Appointment of the Jayawijaya District Forest Area, which is accompanied by a Map of Forest and Water Areas (PKHP), the forest area in Jayawijaya Regency consists of nature reserves, protected forests, limited production forests, production forests and other usage areas.

Within the forest area there are several designations, namely production forest (Forestry Cultivation area) land reserve for non-forest and conversion forest (Non-Forestry Cultivation Area, Other Use Areas) and forest to maintain biodiversity and ecosystem protection (conservation forest and protected forest).

\subsection{Area of Forest Area in Jayawijaya Regency}

According to BPS sources, the area of Jayawijaya, is a land area of $13925.31 \mathrm{~km} 2$. Meanwhile, the forest area in Jayawijaya Regency is decreasing compared with the previous year, while the forest area in 2012 is still the same as the year2011, in 2010 the area of forest area is $849,600 \mathrm{Ha}$ and it is now $168,025 \mathrm{Ha}$. The forest area consists of production forest (4.992,63 Ha), conversion production forest $(45,077,507 \mathrm{Ha})$, Protected Forest $(11,557.06 \mathrm{Ha})$ Conversion forest $(52,004.93 \mathrm{Ha})$ and other mountainous areas $(54,393,654 \mathrm{Ha})$.

When viewed from the production of forest products, especially sawn timber in 2010 as much as $2,507.30 \mathrm{~m} 3$ increased to $5,444.35 \mathrm{~m} 3$ in 2011 . Regional original revenues from forest products also experienced an increase of 195,000,000 to 815,000,000. This decrease in forest area was due to the high pressure by the surrounding residents to be able to take advantage of the economic opportunities in the area into agricultural, plantation, settlement, fulfillment of fuel wood and most of the production of forest products in the form of sawn timber. This unbalanced forest utilization will certainly result in a decrease in environmental quality accompanied by damage to the forest.

\subsection{Implementation of Agroforestry Programs}

Currently forest management in Jayawijaya District has undergone a policy change that will affect both now and in the future. However, there is also a condition that increases the insecurity of forest resources, namely population growth and rapid development of the region which has the consequence of increasing the need for natural resources. This pressure will cause the rate of degradation of natural resources, especially forests in the surrounding forest area to be increasingly greater by utilizing the transfer of functions of land needs for the use of wood for buildings, firewood, and others. This condition will disturb the natural ecosystem of the forest. Therefore, the weakness of forest conservation efforts is still an important problem that must be resolved both through policy discussions and their implementation and other efforts.. 


\subsection{Community Empowerment}

In the implementation of the Agroforestry Program in Jayawijaya Regency, which is a government program implemented in the Walelagama District conducted in 2015 to 2017 in an effort to conserve district government forests through UPTD KPHL Jayawijaya has carried out a policy of guidance and instruction to the community. This is directed to forest ecosystems where the lives of people around the forest cannot be separated from their ecosystems. This is manifested in the form of kinship relations between citizens and the reciprocal relationship between humans and the natural surroundings. The relationship will ultimately give a characteristic to the life of the district community. Therefore, community empowerment through agroforesty programs is very appropriate in implementing government policies, especially looking at forest ecosystems having some characteristics in terms of the interests of natural resources where forests have high economic value potential, and forests as natural resources that can restored utilization requires proper management, as far as possible to prevent environmental pollution and ensure its sustainability for present and future needs.

From several interviews with resource persons from both technical personnel and community leaders, the government has not yet implemented policies for forest conservation because people in their activities use the forest in order to meet their needs so that forest destruction includes massive deforestation for fuel per day, people also make it to get additional daily income, even those who are not less drained of wood in the forest are the habits or customs of the people who cut wood to make a garden fence to overcome or protect the entry of their pets. And this requires a lot of wood as a material for making fences. In addition, logging is carried out on a large scale for home-made materials that are quite promising from an economic standpoint.

Field findings in several places that forest ecosystems have been changed completely into other ecosystems. There is a big threat to forest areas that have not been disturbed and further degradation of some areas that are under pressure both due to natural and human actions.

Issues that arise around the implementation of agroforestry programs around the forest area have been carried out by the related institutions by conducting various counseling but the lack of resources such as social capital owned by the community with low education, facilities in the form of facilities and infrastructure and costs that support the existence of the policy. Oriented on these issues, based on the experience from 2011 to 2014, the preservation of forest areas in the Walelagama District area of Jayawijaya Regency was used in an uncontrolled manner. This dual use of various sectors and excessive use of resources has caused forest damage.

Responding to this, to increase forest productivity without damaging its existence can be developed integrated system cultivation for example by planting agricultural crops such as: coffee, corn, Hipere, cabbage, mustard greens, and other agricultural crops in forest areas can be used as cultivation crops. In the case of community empowerment, it is necessary to pay attention to the real aspects that can be considered to restore damaged forest ecosystems, including: (a) excessive exploitation or continuous deforestation for firewood and fencing, (b) erosion problems in forest areas.

Based on the description above, the implementation of the community empowerment policy through the Agroforestry program in the context of preserving forest areas in the Walelagama District of Jayawijaya District requires a vertical and horizontal approach, because the efforts to restore forest ecosystems must be carried out by the local government supported by budget and personnel and participation society. 


\subsection{Management of Agroforestry Programs}

The Agroforestry program implemented by the local government of Jayawijaya Regency is a combination of agricultural cultivation to maintain forest sustainability. Efforts made by this government bring significant results and provide public awareness to be involved in the implementation of the program. The management of agroforestry programs in the Jayawijaya Regency area is based on three main stages, namely: ecological and socioeconomic, institutional and legal instruments, and strategy and implementation of plans.

Ecology includes the ecological impact of community intervention on forest ecosystems. Various impacts of community activities on forest ecosystems must be identified, both those that have occurred and those that will occur in the future. As for socio-economics, it covers aspects of the habits of communities around the forest in utilizing forest resources [6].

Furthermore, in the institutional system and legal instruments, the Ministry of Forestry is an institution that is very competent in forest management. Coordination between agencies related to forest management is to be done now. The legal aspects of the instrument are the regulations and laws related to forest management. There are quite a number of regulatory systems made by the government and related agencies in forest management. What is needed now is law enforcement for violations of the legal instruments.

Related to this, the strategy and implementation of the plan within the framework of forest management and conservation, there are two main concepts that can be applied. Both concepts basically provide legitimacy and understanding that forests are in desperate need of management and protection in order to remain sustainable. Both concepts are forest protection and forest rehabilitation [7]. One way that can be done in order to protect the existence of forests is to designate a forest area to be used as a conservation area.

Responding to the above that forest management in the forest ecosystem area in Jayawijaya Regency in addition to the forest area there is also an area / land that is not a forest area, usually the status of this forest is managed by the community as the owner of the land used for agricultural cultivation, and so on. At present a pattern of supervision of participatory forest ecosystem management has been developed that involves the community. This idea was developed based on the premise that relatively poor people must be involved in forest management by means of empowerment, both their ability (knowledge) and the economy. The supervisory pattern of forest ecosystem management developed is a participatory pattern including: supervised components, policy socialization and transparency, formal institutions that oversee, parties involved in supervision, oversight mechanisms, and incentives and sanctions.

\subsection{Factors affecting the Implementation of Local Government Policies in Forest Conservation}

The implementation of the Agroforestry program in empowering forest communities in Walelagama District in Jayawijaya Regency is strongly influenced by several factors :

\section{a. Communication Factors}

From several interviews with several speakers, it can be concluded that the government must be wise with the delays in the issuance of regulations and lack of counseling so as to provide opportunities for the community to convert forest areas. Therefore, it is necessary to have the participation of all parties and not only accumulate in the government because later policies, regulations and their implementation will have weaknesses. Therefore, the communication strategy in order to strengthen the community is an important part of efforts to 
conserve forest areas through agroforestry programs. With their awareness and care, the community participates in guarding the area, because its economic resources depend on the region.

In addition, there is a lack of synergy between the government and the community in communicating about the Agroforestry program.

\section{b. Disposition Factor (Attitude)}

Seeing the conditions on the ground in implementing the Agroforestry program is strongly influenced by the attitude of the policy implementers themselves, namely the Jayawijaya forestry service. The attitude of the implementers to implement the intent and purpose of the agroforestry program to succeed effectively and efficiently, the implementors not only have to know what they have to do but must have the ability to implement the policy. Thus the technical implementers have attempted to carry out the duties and responsibilities that exist but many people do not really understand the intent and purpose of the use and preservation of forest areas. By looking at this condition, the local government needs to optimize its socialization, coordinate with district heads, village heads, community leaders, NGOs and even communities in the forest area to provide more understanding and also be accompanied by persuasive approaches and special abilities by field technical implementers in responding to community attitudes.

As a facilitator and monitor of activities and supervision as a whole, based on the certainty of the rights and obligations of all parties. Government support, should have begun to try to realize its efforts to reinforce community rights. In the community law policy about actively involving the community in the implementation of the program, which is very much different from the previous policies.

The most essential damage to forest areas is due to the commitment of the government that is less heed to the preservation rules with the forced policy of forest as the main source in sustaining development. Considering these conditions, the required target is to improve the condition of the forest area through the Agroforestry program and the planting and rehabilitation of forests which need to be given attention by the local government.

In the forestry program that has been carried out by the local government the implementation of the 2015-2017 Agroforestry program in Jayawijaya where the implementation location is in the Walelagama District with an area of $40 \mathrm{Ha}$.

The attitude that needs to be considered by the local government is to optimize the use of natural forests and the development of plantations and non-timber forest products in a sustainable manner with the subsequent environmental management, it is necessary to consider increasing the production of non-timber products for the welfare of the community around the forest area, where necessary guidance and empowerment forest products for the welfare of the community and the need for transparency and participatory government attitudes and behavior in forest management and active participation of the community in the decision-making process, planning and implementation, as well as control and supervision of the implementation of the agorforestry program is one form and key to the success of every business and sustainable forest conservation efforts.

\section{c. Resource Factor}

Resource factors have an important role in agroforestry implementation, the accuracy or feasibility between the number of staff needed and the expertise that must be possessed with the task to be done. Funds to finance the operationalization of the implementation of the program, relevant and sufficient information about how to implement a policy, and the 
willingness or ability of various parties involved in implementing the policy. This will affect the authority not guarantee or ensure that the policies implemented are in accordance with what they want, because the facilities used for operations in the field are very limited. Disclosing this matter that with limited personnel, as data obtained from the UPTD that forestry police and technical officers are very lacking, which is 6 people, for technical officers / extension agents and supervision of forest preservation do not yet exist.

This condition has an impact on the direction of policies taken in efforts to conserve forest areas, namely to optimize forest use and the development of illegally planted forests and nontimber forest products by the community. This also has an impact on the policy implementation by the district government itself, that is freely the community can freely penetrate the forest according to their needs. Furthermore, the funds available in the Agroforestry program in Jayawijaya still need more special attention. This provision of funds must be adjusted to the condition of the forest. While the limited costs that are so minimal for preserving and conserving forest areas through the Agroforestry program cannot work well. By swallowing so many budgets and of course all of this cannot be separated from the field workers who have to supervise in the field and it will be effective if it involves various parties. In addition, the low resources involved in managing the Agroforestry program both in terms of facilities and infrastructure and in terms of human resources and available funds. However, it also needs to be understood that by fully involving other stakeholders, the scarcity of resources can now be covered. Thus all the processes of the Agroforestry program, which starts from the process of planting and plant maintanance, are carried out by the community. Through this mechanism, the community does not feel considered irresponsible, but rather owns the forest, because they feel that they are planning to plant planting and others concerning the preservation of the forest. The community has a stake in the effort to conserve the forest, so that their status will change became the people who are responsible and share the forest.

\section{d. Bureaucratic structure}

One of the supporters of the success of a policy is that the implementing agency can run effectively and efficiently. However, the implementation of agroforestry programs by the implementing bureaucrats has not gone well. It appears that there is a lack of functioning of oversight such as NGOs, and the Regional Government, namely Jayawijaya KPHL UPTD. The existence of policies in the field implementation is less effective. So it is not surprising that then the existing devices freely carry out policies that are not directed towards the sustainability of the Forest Areas.

Therefore, the awareness and concern of the community here is not in the narrow terms (ordinary people) but in broad terms (stakeholders) or what is called the parties concerned (community, NGOs, and executives government and legislative) on environmental management or conservation. Based on the results of field observations there are several main issues as explained above, it can be said that the level of awareness and concern of the parties concerned with environmental sustainability is still relatively low. As an indicator of the low awareness and concern of stakeholders on environmental sustainability, especially the preservation of the utilization of Forest Areas in the Jayawijaya Regency, namely the ongoing activities of forest destruction [8].

An effective bureaucratic structure can be realized in forestry development programs and community forest development, namely the existence of agroforestry and critical land activities with fast growing plants and high economic value by pioneering industrial plantation forests that are able to create linkages with the economic activities of small, medium and 
cooperative businesses which is directed at the development of community forests by introducing species of high economic value and short life; and fostering and enhancing ecological awareness and conservation of the community in the effort to conserve and utilize forest areas.

It also needs to be addressed that the uncertainty of tenure and ownership of land for both the community and industry contributes to the degradation of land and forest areas and, in many cases, causes a conflict. Therefore, the existing problems are uncertainty about local government policies and the rules of the game set by the Ministry of Forestry. An authority and policy taken is not accompanied by the ability to manage the forest area and is unable to provide guarantees of control and management needed by both the local community and the forestry industry. This is further compounded by the lack of seriousness of the central government in delegating forest management professionally to the regions.

One alternative in optimizing forest potential is to optimize existing local resources, for example the community, customary law, habits or behavior of the community or the culture itself.

\section{Conclusion}

The implementation of the community empowerment policy through the Agroforestry program in the context of preserving forest areas in the Walelagama District of Jayawijaya Regency requires an approach both vertically and horizontally, because the efforts to restore forest ecosystems must be carried out by the local government that is supported by a budget and personnel and full community participation and Management Agroforestry programs in the Jayawijaya Regency area are based on three main stages, namely: ecological and socioeconomic, institutional and legal tools, as well as strategy and implementation of plans.

The implementation of the Agroforestry program in empowering forest communities in Walelagama District in Jayawijaya is strongly influenced by several factors, namely first, communication, how to inform as easily as possible can be understood by the community's goals and objectives of the policy taken. Second, the bureaucratic structure, which is supported by implementing institutions that are not complicated and simple. Third, resources, the availability of financial resources, power and facilities in the form of adequate facilities and infrastructure. Fourth, the disposition factor as the attitude of the implementers to implement programs that have an important role in program implementation, because no matter how clear and consistent the provisions are or the rules of a policy, it is need to be supported by a responsible attitude and implementer.

\section{References}

[1] W. R. Ginanjar and A. Z. Mubarrok, "Civil Society and Global Governance: The Indirect Participation of Extinction Rebellion in Global Governance on Climate Change," J. Contemp. Gov. Public Policy, vol. 1, no. 1, pp. 41-52, 2020.

[2] A. Taufik, H. Hamrun, and A. Harakan, "Implementasi Good Forest Governance Dalam Pengelolaan Hutan Lindung di Kabupaten Bantaeng," J. Anal. Sos. Polit., vol. 1, no. 1, 2017.

[3] H. Syaukani, A. Gaffar, and M. R. Rasyid, Otonomi daerah : Dalam negara kesatuan. Yogyakarta: Pustaka Pelajar, 2002. 
[4] S. A. Wahab, Analisis Kebijaksanaan dari Formulasi ke Implementasi Kebijakan Negara. Jakarta: PT Bumi Aksara, 2008.

[5] W. Budi, Kebijakan Publik (Teori, Proses, dan Studi Kasus). 2014.

[6] B. Arts, "Assessing forest governance from a 'Triple G' perspective: Government, governance, governmentality*," For. Policy Econ., 2014.

[7] P. J. Kanowski, C. L. McDermott, and B. W. Cashore, "Implementing REDD+: Lessons from analysis of forest governance," Environ. Sci. Policy, 2011.

[8] L. Persha, A. Agrawal, and A. Chhatre, "Social and ecological synergy: Local rulemaking, forest livelihoods, and biodiversity conservation," Science (80-. )., 2011. 